\title{
Physiological and molecular studies on ISSR in two wheat cultivars after exposing to gamma radiation
}

\author{
Amina A. Aly*, Noha E. Eliwa, Rabab W. Maraei \\ Natural Products Department, National Centre for Radiation Research and Technology, \\ Atomic Energy Authority, Nasr City, Cairo, Egypt \\ *Corresponding author, e-mail: aly_amina@yahoo.co.uk
}

Received $17 \mathrm{Feb} 2019$

Accepted 8 Aug 2019

\begin{abstract}
Grains of two bread wheat cultivars (Triticum aestivum), Sids-1 and Sakha-93, were irradiated with gamma rays at dose levels $(0.0,100,200$, and $300 \mathrm{~Gy})$ to study the effects of gamma irradiation on physiological characteristics and genetic variation of wheat. Irradiation dose level of $200 \mathrm{~Gy}$ increased chlorophyll a, b, and total chlorophyll contents significantly in both cultivars. Also, proline content increased with increasing irradiation dose level, the highest concentrations were recorded at 300 Gy for Sids-1 and Sakha-93 cultivars as compared to the control. InterSimple Sequence Repeat (ISSR) markers have been done to help understanding their genetic differences. Eight ISSR primers (14A, 44B, HB-08, HB-10, HB-11, HB-12, HB-13, and HB-15) exhibited polymorphism with the un-irradiated and irradiated two wheat cultivars. These pimers successfully showed different banding patterns with several amplicons varied from 4 for (14A) to 15 for (HB-10). These 72 amplicons for the two cultivars and an average of 9.0 amplicons with mean of $67.96 \%$ polymorphism and resolving power (Rp) of 3.41. It is also cleared that radiation is more effective on Sids-1 cultivar with $55.5 \%$ polymorphism than on Sakha-93 cultivar with $51.9 \%$ polymorphism. Total amplicons found in Sids-1cultivar were 64, ten of them were unique amplicons (UA): $5 \mathrm{UA}(+)$ and $5 \mathrm{UA}(-)$. Irradiation dose (200 Gy) showed the highest number of UA (3 UA- and $3 \mathrm{UA}+$ ) in Sids-1cultivar. While, total amplicons found in Sakha-93 cultivar were 58, eight of them were $5 \mathrm{UA}(+)$ and $3 \mathrm{UA}(-)$. Irradiation dose (300 Gy) showed the highest number of UA as $4 \mathrm{UA}+$. It could be concluded that gamma irradiation of wheat grains produced an appropriate number of generated variations and that ISSR analysis given a useful molecular marker for the symmetry of the mutants.
\end{abstract}

KEYWORDS: wheat, inter simple sequence repeat ISSR markers, gamma radiation

\section{INTRODUCTION}

Wheat (Triticum aestivum) is an important staple crop around the world, its importance has increased due to experienced food storages and its role in world trade. Wheat occupied the first place among the cereal crops, ranging $30 \%$ of all cereal food in the world and main food for over one-third of world people that supplies about $20 \%$ of the total food calories directly or indirectly for humankind. To meet higher demands by increasing population, wheat production must be increased ${ }^{1}$. Previously, morphological, cytogenetic, pedigree or chemical analysis were used to investigate plant diversity ${ }^{2}$. Estimation of genetic diversity using molecular markers is a basis for realizing genomic structure, the characterization and maintenance of genetic variation in plant germplasm, identifying genes underlying important traits and applying optimal breeding strategies for crop improvement ${ }^{3}$. Using markers and realization of polymorphic nucleotide sequences dispersed throughout the genome have given new facilities for evaluation, diversity and detecting of inter and intra-species genetic relationships $^{4}$. Several molecular markers are available for investigation of genetic diversity. The ISSR marker overcomes most of these molecular markers, where, they have advantage of relatively low cost, high polymorphism and good reproducibility. It is considered as a new method of molecular markers, is based on inter tandem repeats of short DNA sequences. These inter repeats are highly polymorphic in their sizes even among closely related genotypes as the result of the deficiency of evolutionary functional constraints in these functioning regions. Also, it is a technique that is widely used for assessing the alteration in DNA sequences induced by mutagenic agents such as gamma rays ${ }^{5}$. Additionally, ISSRs have been used successfully in genome mapping for a variety of crop species including maize, rice, barley and wheat ${ }^{6,7}$. Gamma irradiation is considered as physical mutagen imposing considerable effects on 
physiological and biochemical processes in plants ${ }^{8}$. Using of gamma irradiation technique represents a significant role in plant breeding programs and genetic studies are aimed to improve yield and produce desirable traits in many crops under both normal and stress conditions ${ }^{9}$. Also, it may cause genetic variability that enable plant breeders to select new genotypes by improving characteristics such as precocity, tolerance to stresses, grain yield and quality ${ }^{10}$. The mutants developed in wheat had great potential for direct release and to include them in cross breeding program ${ }^{11}$. Many studies showed that the relative doses of ionizing irradiation could be useful for acceleration of cell proliferation, germination rate, cell growth, enzyme activity, stress resistance, and crop yields ${ }^{12}$. The biological influence of gamma rays is due to the interaction with atoms or molecules in the cell, especially water to generate new radicals ${ }^{13}$. These radicals can damage or modify important components of plant cells and have been reported to affect differentially the morphology, anatomy, biochemistry and physiology of plants depending on the irradiation dose level ${ }^{14}$. Furthermore, irradiation by gamma rays leads to increase the level of DNA break formation that can be mitigated through direct identification of genotypes with DNA based assays ${ }^{15}$.

The aim of this work was to determine the effect of gamma irradiation on some physiological characteristics as well as genetic variability detected with ISSR markers. Also, the genetic diversity and relationships between Sids-1 and Sakha-93 wheat cultivars.

\section{MATERIALS AND METHODS}

\section{Plant materials}

Grain of two bread wheat cultivars (Triticum aestivum), Sids-1 and Sakha-93, used in the present study were obtained from Agriculture Research Centre, Ministry of Agriculture, Giza, Egypt. The two cultivars were irradiated with gamma rays at dose levels $(0.0,100,200$, and $300 \mathrm{~Gy}$ with a dose rate of $1.9 \mathrm{kGy} / \mathrm{h}$ ). The source of irradiation was installed at the National Centre for Radiation Research and technology, Atomic Energy Authority, Nasr City, Cairo, Egypt. Irradiated and un-irradiated grains were sown at the experimental farm belonging to the Natural Products Department, to obtain $\mathrm{M}_{1}$ of the grains. Soil mechanical and chemical analysis was performed ${ }^{14}$.

Four plants per replicate were randomly chosen for determining photosynthetic pigments and pro- line content.

\section{Determination of photosynthetic pigments}

Chlorophyll a, b and carotenoids were determined in wheat leaves by the spectrophotometric method ${ }^{16}$. Fresh samples $(0.5 \mathrm{~g})$ were homogenized in a mortar with $85 \%$ acetone in the presence of washed dried sand and a little amount of $\mathrm{CaCO}_{3}(\approx 0.1 \mathrm{~g})$ to neutralize organic acids in the homogenate. The homogenate was then filtered through sintered glass funnel. The residue was washed several times with acetone until the filtrate became colourless. The combined extract was completed to a known volume. The optical density of obtained extract was determined at $662,644 \mathrm{~nm}$ for chlorophyll a and chlorophyll b, respectively, and $440.5 \mathrm{~nm}$ for carotenoids. The pigment contents were calculated as $\mathrm{mg} / \mathrm{g}$ fresh weight. The concentration of chlorophyll a, b and carotenoids were calculated by the formula (in $\mathrm{mg} / \mathrm{l}$ ):

$$
\begin{aligned}
& \text { Chlorophyll } \mathrm{a}=9.784 \times A_{662}-0.99 \times A_{644}, \\
& \text { Chlorophyll } \mathrm{b}=21.426 \times A_{644}-4.65 \times A_{662}, \\
& \text { Carotenoid }=4.695 \times A_{440.5}-0.268 \times c(\mathrm{a}+\mathrm{b}),
\end{aligned}
$$

where $c(\mathrm{a}+\mathrm{b})$ is the sum of chlorophyll $\mathrm{a}$ and $\mathrm{b}$ in $\mathrm{mg} / \mathrm{l}$. The results were calculated as $\mathrm{mg} / \mathrm{g}$ fresh weight.

\section{Determination of proline content}

Proline content was determined by the method of Bates ${ }^{17}$. In brief, $100 \mathrm{mg}$ of frozen plant materials were homogenized in $1.5 \mathrm{ml}$ of $3 \%$ sulphosalicylic acid and the residue was removed by centrifugation. Two $\mathrm{ml}$ glacial acetic acid and $2 \mathrm{ml}$ acid ninhydrin reagent (1.25 g ninhydrin warmed in $30 \mathrm{ml}$ glacial acetic acid and $20 \mathrm{ml} 6 \mathrm{M}$ phosphoric acid until dissolved) were added to $100 \mu \mathrm{l}$ of the extract for $1 \mathrm{~h}$ at $100^{\circ} \mathrm{C}$ and the reaction was then completed in an ice bath. One $\mathrm{ml}$ of toluene was added to the mixture, then warmed to room temperature and its optical density was measured at $520 \mathrm{~nm}$. The amount of proline was determined from a standard curve in the range of $20-100 \mu \mathrm{g}$. The results were expressed as $\mathrm{mg} / \mathrm{g}$ of proline equivalent of the fresh weight of the samples.

\section{Genomic DNA isolation for ISSR analysis}

Total genomic DNA was isolated and purified from frozen $\mathrm{M}_{1}$ leaves of the un-irradiated and irradiated two wheat cultivars using DNeasy plant Mini Kit (QIAGEN, Chatsworth, CA). The concentration of DNA was determined at a wavelength of $260 / 280 \mathrm{~nm}$ and 
Table 1 List of primers (ID) and their nucleotide sequences used in the PCR analysis for ISSR procedure.

\begin{tabular}{lcl}
\hline No. & ID & sequence \\
\hline 1 & 14A & 5'-CTC TCT CTC TCT CTC TTG -3' \\
2 & 44B & 5'-CTC TCT CTC TCT CTC TGC -3' \\
3 & HB-08 & $5^{\prime}$-GAG AGA GAG AGA GG -3' \\
4 & HB-10 & $5^{\prime}$-GAG AGA GAG AGA CC -3' \\
5 & HB-11 & $5^{\prime}$-GTG TGT GTG TGT TGT CC -3' \\
6 & HB-12 & $5^{\prime}$-CAC CACCAC GC -3' \\
7 & HB-13 & $5^{\prime}$-GAG GAGGAG GC -3' \\
8 & HB-15 & $5^{\prime}$-GTG GTGGTG GC -3' \\
\hline
\end{tabular}

the quality was verified by electrophoresis on $1.4 \%$ agarose gel.

\section{ISSR-PCR analysis: polymerase chain reaction}

ISSR-PCR reactions were performed using twenty random primers, amplification was conducted in $25 \mu \mathrm{l}$ reaction volume containing the following reagents: $2.5 \mu \mathrm{l}$ each of dNTPs $(2.5 \mathrm{mM})$, $\mathrm{MgCl}_{2}(2.5 \mathrm{mM})$, and $10 \times$ buffer, $3.0 \mu \mathrm{l}$ of primer (10 pmol), $3.0 \mu \mathrm{l}$ of template DNA $(25 \mathrm{mg} / \mu \mathrm{l})$, $1 \mu \mathrm{l}$ of Taq polymerase $(1 \mathrm{U} / \mu \mathrm{l})$, and $12.5 \mu \mathrm{l}$ of sterile $\mathrm{H}_{2} \mathrm{O}$. The PCRs (Techni TC-512 PCR System) were programmed for one cycle at $94^{\circ} \mathrm{C}$ for $4 \mathrm{~min}$. followed by 45 cycles of $1 \mathrm{~min}$ at $94^{\circ} \mathrm{C}, 1 \mathrm{~min}$ at $57^{\circ} \mathrm{C}$, and $2 \mathrm{~min}$ at $72^{\circ} \mathrm{C}$ the reaction was finally stored at $72{ }^{\circ} \mathrm{C}$ for $10 \mathrm{~min}$. The PCR products were separated on $2 \%$ agarose gels and fragment sizes were estimated with the 100 bpDNA ladder. Only eight from 20 primers succeeded to generate reproducible polymorphic PCR products. Table 1 lists the base sequences of these DNA primers that produced informative polymorphic amplicons.

\section{Statistical analysis}

A complete randomized block design with three replicates was used. The data were presented as the mean $\pm \mathrm{SD}$. All the statistical analyses were performed using an ANOVA, and Duncan's multiple range tests ${ }^{18}$ was applied to compare the results of the experiments $(p \leqslant 0.05)$.

\section{Molecular analysis}

DNA banding pattern of each primer were analysed by GELANALYSER3 software which scoring clear amplicons as present (1) or absent (0) for each primer in binary data matrix. From this matrix, resolving power (Rp) of each primer was calculated according to Prevost and Wilkinson ${ }^{19}$ using the formula:

$$
\mathrm{Rp}=\sum I_{b}, \quad I_{b}=1-(2 \times|0.5-p|),
$$

where, $I_{b}$ (amplicon in formativeness) was calculated for each amplicon scored individually by the primer, $p$ being the ratio of studied lines containing the $I$ amplicon.

Also, cluster analysis and similarity index were performed from binary data using agglomerative hierarchical clustering derived from unweighted pairgroup average UPGMA method by XLSTAT.7 computational software.

\section{RESULTS AND DISCUSSION}

\section{Chlorophyll content}

The estimation of important biochemical characteristics such as chlorophyll a, b and carotenoids contents in the two Egyptian wheat cultivars (Sids1 and Sakha-93) are presented in Fig. 1 and Fig. 2, respectively. Photosynthesis is one of the most studied processes under the effects of gamma irradiation, a gradual increase in chlorophyll a, b, total chlorophyll, and carotenoids contents have been observed in the present study, which reached the maximum content at the dose level of $200 \mathrm{~Gy}$ $(1.067,0.6239,1.6909$, and $0.333 \mathrm{mg} / \mathrm{g} \mathrm{FW})$, respectively, for Sids- 1 cultivar and (1.344, 0.6092, 1.9532 , and $0.2231 \mathrm{mg} / \mathrm{g} \mathrm{FW}$ ), respectively, for Sakha-93 cultivar. Then all these contents decreased slightly at the dose level of $300 \mathrm{~Gy}(0.8569,0.555$, 1.4119 , and $0.1602 \mathrm{mg} / \mathrm{g} \mathrm{FW}$ ), respectively, for Sids- 1 cultivar and $(0.9487,0.5533,1.502$, and $0.1497 \mathrm{mg} / \mathrm{g} \mathrm{FW}$ ), respectively, for Sakha-93 cultivar. In the same concern, chlorophyll a, b, and total chlorophyll levels significantly increased in wheat with increasing gamma irradiation dose levels until $200 \mathrm{~Gy}^{20}$. In view of this, photosynthetic pigments can be highly decreased by irradiation high dose levels, with concomitant loss of photosynthetic capacity ${ }^{21}$. According to transmission electron microscope observations, chloroplasts were highly sensitive to gamma radiation compared to other cell organelles, especially thylakoids being heavy swollen ${ }^{9}$. Likewise, a high dose of gamma rays up to $500 \mathrm{~Gy}$ reduced chlorophyll content by $80.9 \%$ and reduced the organized structure of grana and stroma thylakoid ${ }^{22}$.

\section{Proline content}

The results in Fig. 3 showed the effect of different doses of gamma irradiation on the proline content in the two wheat cultivars (Sids-1 and Sakha-93). We found that the content of proline increased by increasing gamma irradiation dose level. Increase in proline content can be helpful in maintaining 

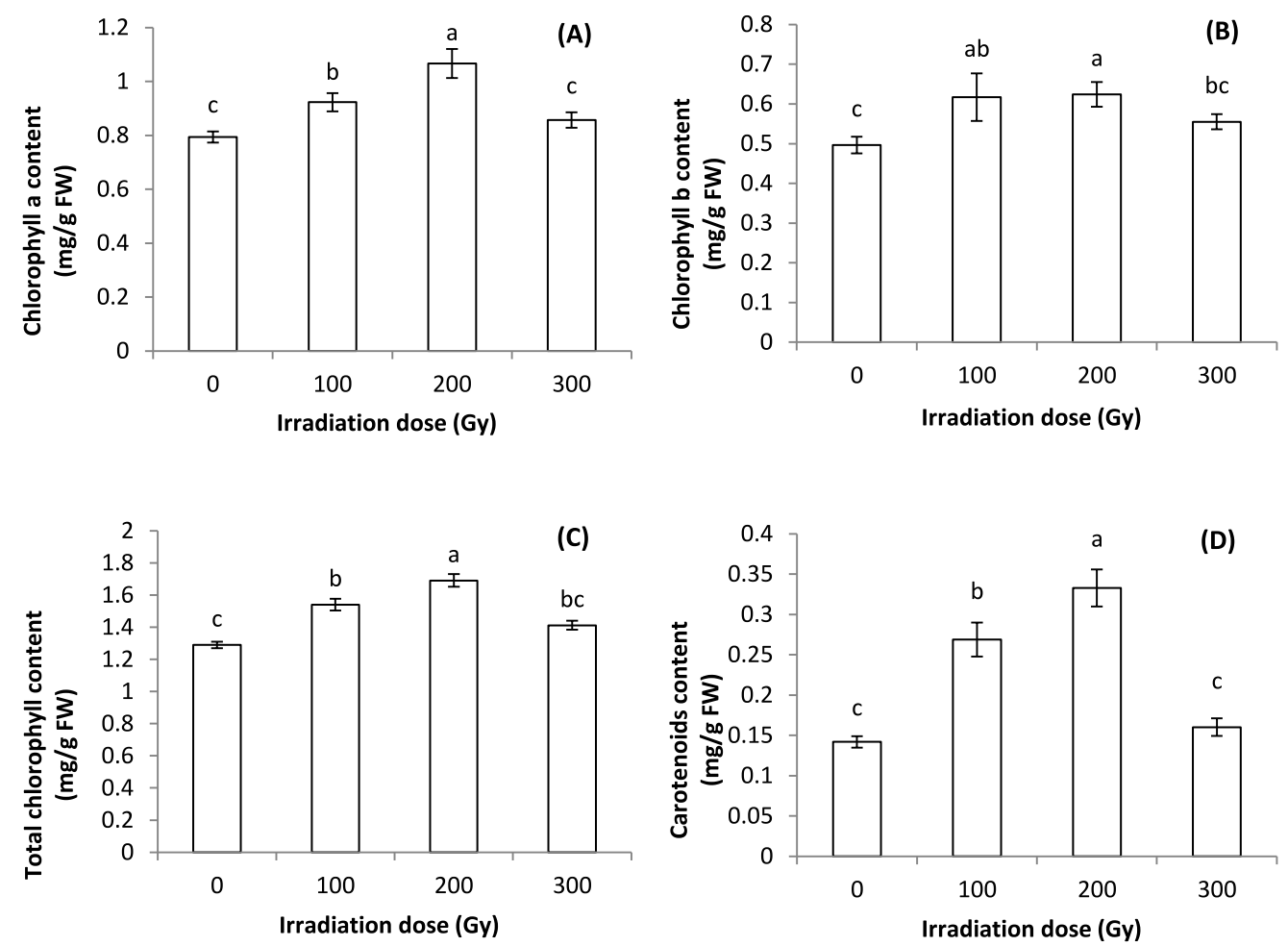

Fig. 1 Effect of gamma irradiation on chlorophyll a (A), chlorophyll b (B), total chlorophyll (C), and carotenoid (D) contents (mg/g FW) of Sids-1 Egyptian wheat cultivar. Vertical bars show SD $(n=3)$ and different letters indicate statistically significant differences at $p \leqslant 0.05$.
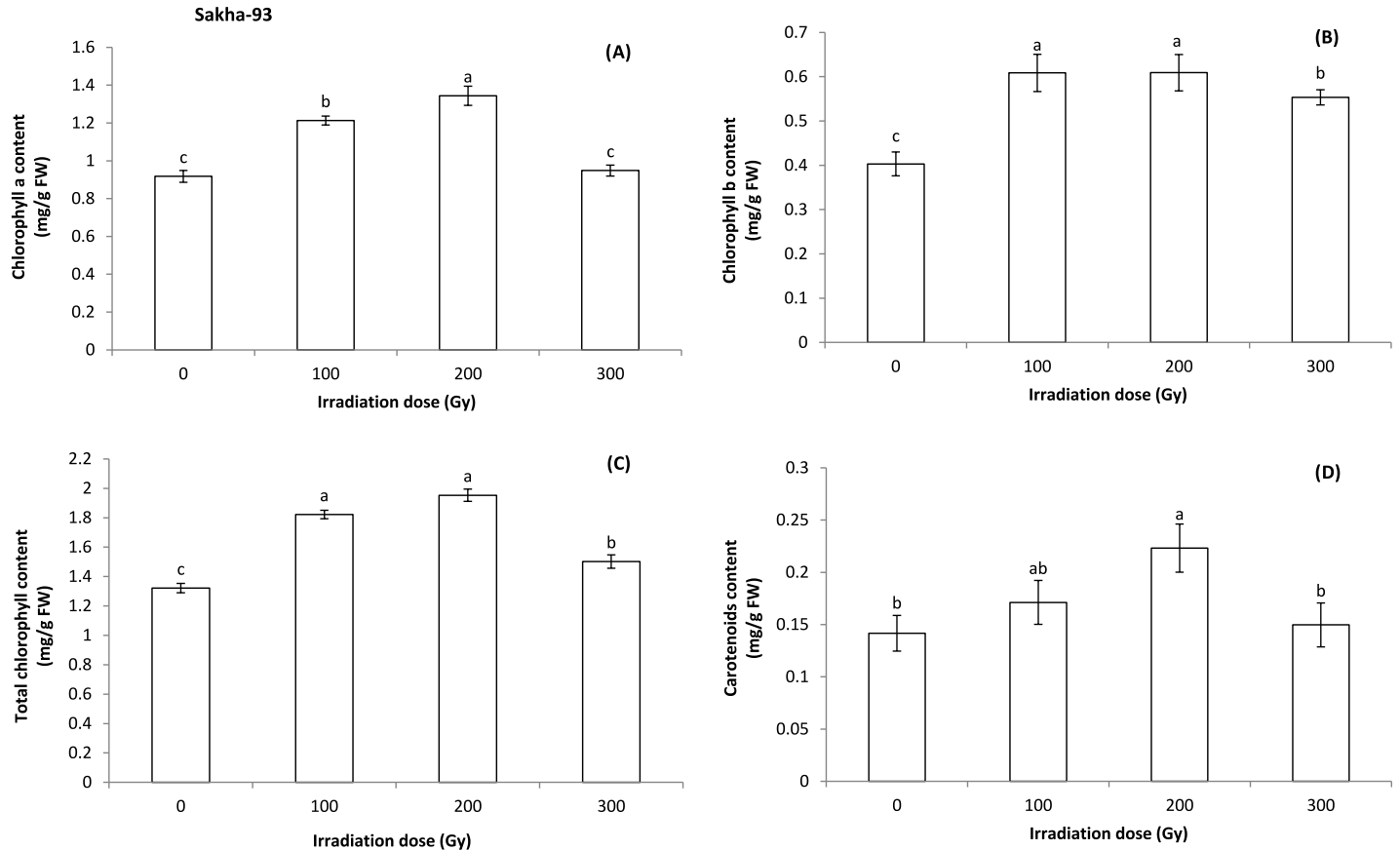

Fig. 2 Effect of gamma irradiation on chlorophyll a (A), chlorophyll b (B), total chlorophyll (C), and carotenoid (D) contents (mg/g FW) of Sakha-93 Egyptian wheat cultivar. Vertical bars show SD $(n=3)$ and different letters indicate statistically significant differences at $p \leqslant 0.05$. 

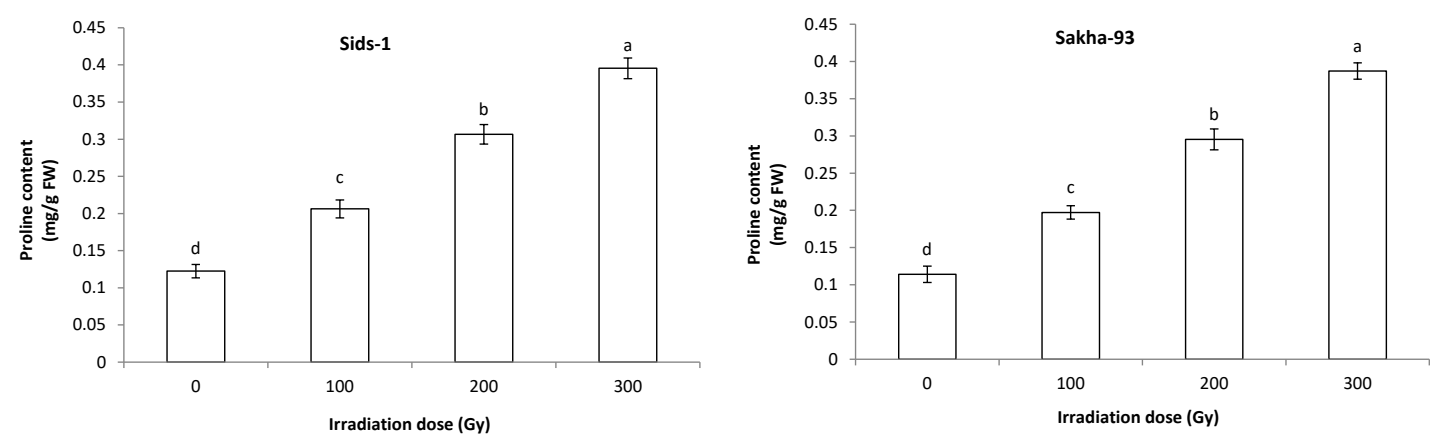

Fig. 3 Effect of gamma irradiation on proline content (mg/g FW) of Sids-1 and Sakha-93 Egyptian wheat cultivars. Vertical bars show SD $(n=3)$ and different letters indicate statistically significant differences at $p \leqslant 0.05$.

osmoticum under various environmental stresses. In the present study, the highest concentrations ( 0.3954 and $0.3870 \mathrm{mg} / \mathrm{g} \mathrm{FW}$ ) were recorded at 300 Gy for Sids- 1 and Sakha-93 cultivars, compared to the control $(0.1225$ and $0.1142 \mathrm{mg} / \mathrm{g} \mathrm{FW})$ for Sids-1 and Sakha-93 cultivars, respectively. Increase proline content with increasing irradiation dose level in the present study confirms the role of proline as a compatible solute. These results are in agreements with Akshatha et $\mathrm{al}^{23}$ who reported that the proline content increased with increasing irradiation doses in Terminalia arjuna Roxb. Also, Aly et $\mathrm{al}^{14}$ reported that exposure to gamma rays significantly increased proline accumulation in wheat leaves especially at dose level $300 \mathrm{~Gy}$ in $\mathrm{M}_{2}$. Ionizing radiation enhanced proline content referring that proline has an important role in the defence systems against gamma rays ${ }^{22}$. Radiation stimulates formation of reactive oxygen species (ROS), which is extremely toxic to plant cells. Proline serves as scavenger of ROS and can maintain the structure and function of macromolecules such as DNA, protein and membranes ${ }^{24}$. The magic effect may be due to increase proline accumulation in the plant cells. Also, the hydrophilicity of proline and other compatible solutes play great role to placed water molecules around nucleic acid, proteins and membranes during drought period. Hence the interaction of proline and altered proteins causes increase in the stability of proteins ${ }^{25}$. When plants are subjected to water stress they increase their content of proline, this enables to improve the capacity of the cell to maintain its turgor pressure at low water potential. This appears to be essential for physiological processes such as photosynthesis, enzyme activity and cell expansion ${ }^{26}$.
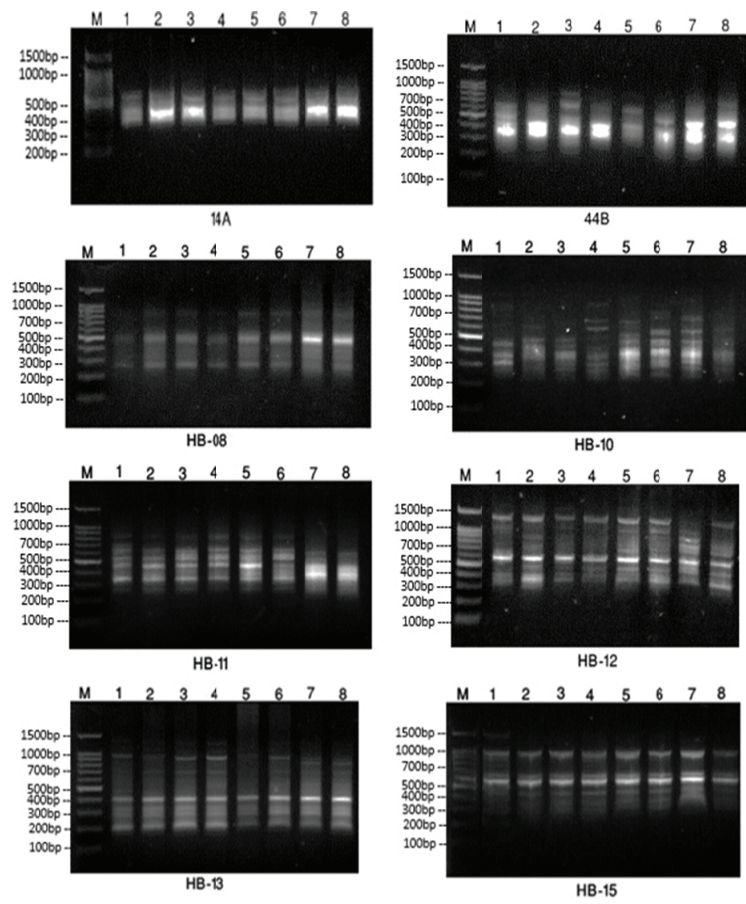

Fig. 4 Agarose gel electrophoresis of ISSR amplifications of the Egyptian two wheat cultivars Sids- 1 and Sakha-93 with primers (14A, 44B, HB-08, HB-10, HB-11, HB-12, HB-13, and HB-15) lane M, DNA marker (100-1500 bp); lane 1 Sids-1 0.0 Gy, lane 2 Sids-1 $100 \mathrm{~Gy}$, lane 3 Sids1200 Gy, lane 4 Sids-1 300 Gy, lane 5 Sakha-93 0.0 Gy, lane 6 Sakh-93 100 Gy, lane 7 Sakha-93 200 Gy, and lane 8 Sakha-93 300 Gy.

\section{ISSR banding patterns}

The ISSR technique has been done in this study for $\mathrm{M}_{1}$ (un-irradiated and irradiated samples to see the induced molecular markers changes), eight ISSR primers (14A, 44B, HB-08, HB-10, HB-11, HB- 


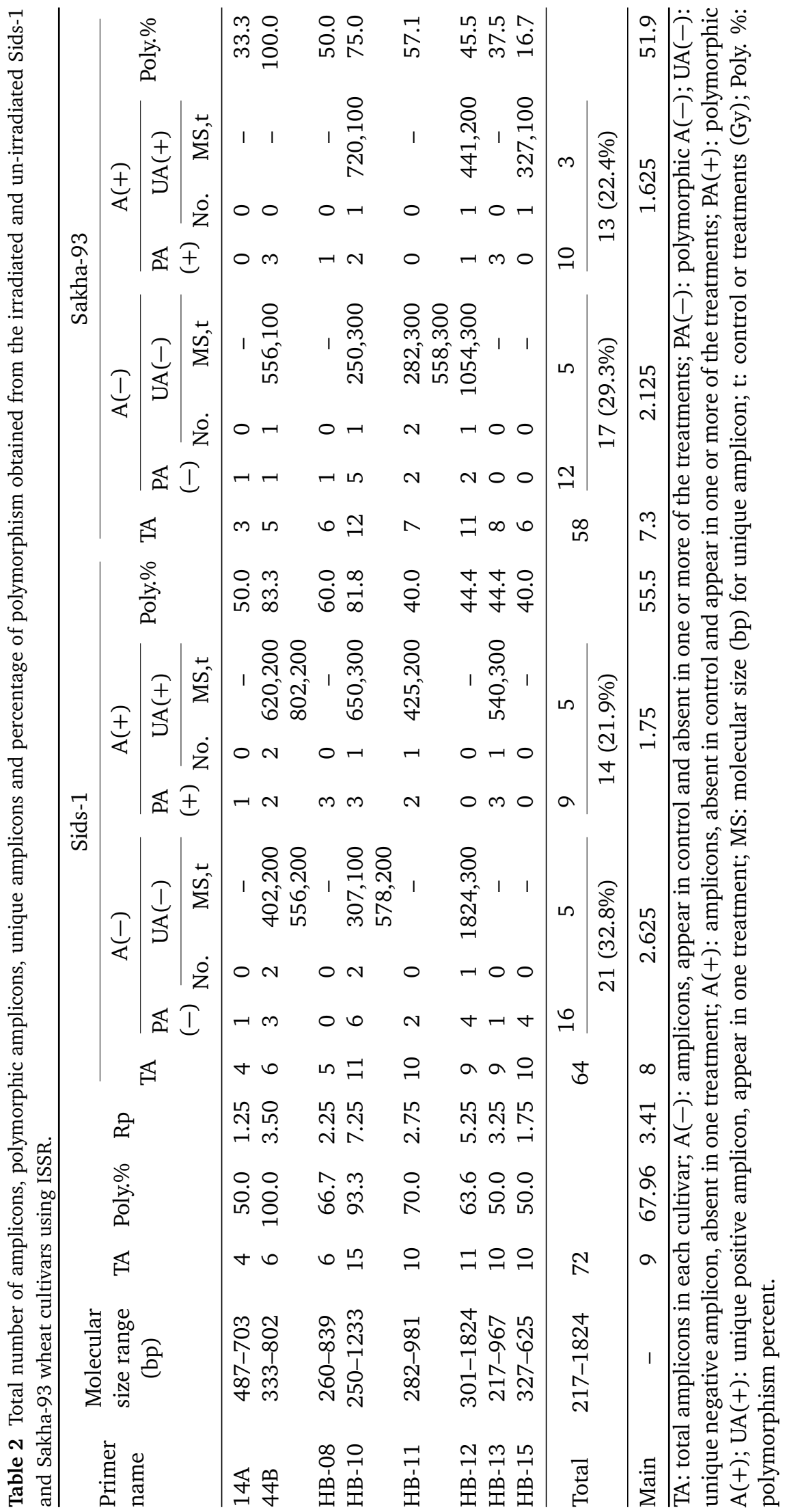


12, HB-13, and HB-15) exhibited polymorphism with the un-irradiated and irradiated two wheat cultivars, Sids-1, and Sakha-93 (Fig. 4 and Table 2). These primers detected total amplification fragments of 72 bands for the two cultivars and at an average of 9.0 bands with mean of polymorphic percentage of $68 \%$ and resolving power (Rp) 3.41. In addition, it is clear from Table 2 that the eight primers out of 20 succeeded in detecting large number of amplicons $\mathrm{A}(+)$ and $\mathrm{A}(-)$ which differ among irradiation treatments and their control of each cultivar. For wheat cultivar Sids-1 and its treatment, all primers successfully showed multiple band profiles (Fig. 4) with several amplicons varied from 4 (for 14A) to 11 (for HB-10), Table 2. In total, 64 amplicons were found, 35 (54.7\%) of them were polymorphic; of which $10(15.6 \%)$ were unique amplicons (UA), $5 \mathrm{UA}(+)$ and $5 \mathrm{UA}(-)$ in Sids1 cultivar. In Sakha-93, total 58 amplicons were found, $30(51.7 \%)$ of them were polymorphic; of which 8 (13.8\%) were unique amplicons, $5 \mathrm{UA}(+)$ and $3 \mathrm{UA}(-)$. The highest number of UA was produced by the primer $44 \mathrm{~B}$ while the primers $14 \mathrm{~A}$, HB-08, and HB-15 showed no appearance of UA amplicons. Furthermore, for wheat cultivar Sakha93 and its treatments, all primers were successfully showed multiple band profiles, with number of amplicons varied from 3 (for 14A) to 12 (for HB-10) (Table 2). In total 58 amplicons, $51.9 \%$ of them were polymorphic. Eight out of 30 amplicons were UA ( 5 negative and 3 positive UA).

Additionally, from data of $\mathrm{A}(-)$ and $\mathrm{A}(+)$ which refer to the effect of treatments on the susceptibility of studied wheat cultivars for compatibility with ISSR primers, these results showed that the percentage of $\mathrm{A}(-)$ was greater in Sids-1 $(\mathrm{A}-\%=32.8)$ than in Sakha-93 $(\mathrm{A}-\%=29.3)$ while, $\mathrm{A}(+)$ was greater in Sakha-93 $(\mathrm{A}+\%=22.4)$ than in Sids$1(\mathrm{~A}+\%=21.9)$. It could be concluded that the 200 Gy treatment of Sids-1 produced the greatest number of individual molecular markers $(+3$ and -3 of total of 10), otherwise the $300 \mathrm{~Gy}$ treatment of Sakha-93 cultivar resulted in the highest number of the individual molecular markers $(+5$ and -3 of total of 8). The best primer in the ability for illustrating the variation induced by gamma irradiation in both cultivars was HB-10. Sids-1 cultivar was most affected by gamma irradiation resulted in variation rate of $55.5 \%$ while only $51.9 \%$ was found in Sakha93 cultivar.

The improvement in each one of the studied two cultivars and in between them could be associated with molecular markers as described in Table 2.
There were $5 \mathrm{UA}(+)$ and $5 \mathrm{UA}(-)$ induced in Sids1 , three of them induced by the treatment $200 \mathrm{~Gy}$. Otherwise, Sakha-93 performed eight amplicons 5 $\mathrm{UA}(+)$ and $3 \mathrm{UA}(-)$, the irradiation dose level 300 Gy was the most effected dose induced four positive amplicons. These amplicons are in accordance with the physiological traits (chlorophyll and proline contents) as the most effective dose for chlorophylls was $200 \mathrm{~Gy}$ and $300 \mathrm{~Gy}$ for proline in the two cultivars.

The ISSR marker was an efficient and reproducible method to assess genetic diversity in wheat (Triticum aestivum), and could be used as highly informative markers for genome mapping and gene tagging because the evolutionary rate of change within microsatellites is considerably higher than many other types of DNA markers. This agreed with, Abd El-Aziz et al ${ }^{27}$ who demonstrated that gamma rays were succeeded for inducing desirable changes in okra at the two phenotypic and molecular levels. Also, Singh and Datta ${ }^{28}$, who reported that gamma irradiation encouraged phenotypic changes in wheat, whereas total leaf mass, plant mass and the tiller number increased three times more than control as a result of gamma irradiation. Gamma radiation at dose levels 50, 100, 200, and $300 \mathrm{~Gy}$ induced more genetic variation in the genotypes of var. Kaha 1 and var. Dokki 331 Cowpea compared to other varieties, as estimated by the cluster analysis of seed protein, RAPD and ISSR markers ${ }^{29}$. In the same concern Žiarovská et $\mathrm{al}^{30}$ indicated that the different ISSR fingerprint patterns of the amaranth mutant lines when compared to the Ficha cultivar and K-433 hybrid, ISSR specific profiles may be part of a consequence of the complex response of the intergenic space of mutant lines to the gamma-radiance. Genetic analysis using ISSR of the different populations of Chinese fir in Fujian province exhibited a greater level of genetic diversity than that generated from the populations in Taiwan ${ }^{31}$. Polylocus ISSR-PCR markers can be used for characterizing gene pools and for molecular genetics identification of populations and breeds, including starlet populations and replacement brood stocks ${ }^{32}$. Disappearance of ISSR bands in some $\mathrm{M}_{1}$ and $\mathrm{M}_{2}$ plants could be referred to damages of DNA like single or double-strand breaks, modified bases, oxidized bases, and bulky adducts. In addition, DNA-protein crosses links, point mutations and rearrangement of chromosomes were induced by gamma irradiation ${ }^{29}$. Furthermore, it has been shown that free radicals interact with biomolecules as DNA and remove electrons from them, so they 
damage both structure and activity of the DNA. During ISSR amplification, as Taq polymerase reaches DNA damage, there could be a blockage by potential dismantling of the enzyme-DNA, which will show the loss of ISSR bands. While, the appearance of new bands may be because of the effect of mutation rather than of DNA damage ${ }^{33}$. Treating plants with highest doses of gamma rays resulted in the highest reduction in content of genomic DNA. Similarly, the appearance or disappearance of bands under gamma irradiation might be considered as molecular markers for radiation processes ${ }^{34}$. It has been exhibited that effects of gamma rays on ISSR fingerprinting might be connected to structural rearrangements in DNA caused by different types of DNA damages ${ }^{35}$. Heiba et $\mathrm{al}^{36}$ demonstrated that, RAPD, ISSR, and SSR markers play vital and successful role to differentiate between all the genotypes used concerning salt stress in wheat which could be helpful in the enhancement of cereals production in Egypt. Also, cited that this technology can be used as an indicator of molecular breeding in wheat, to increase ability of abiotic stress tolerance of the studied lines and using it in local breeding program. Expressions of candidate genes in several major metabolic pathways and stress responses were positively correlated with heat tolerance manifested by the genetic variations in leaf chlorophyll content, photochemical efficiency, and membrane stability in fine fescue cultivars ${ }^{37}$. Elshafei et $\mathrm{al}^{38}$ identified several types of molecular markers associated with the three physiological traits in wheat
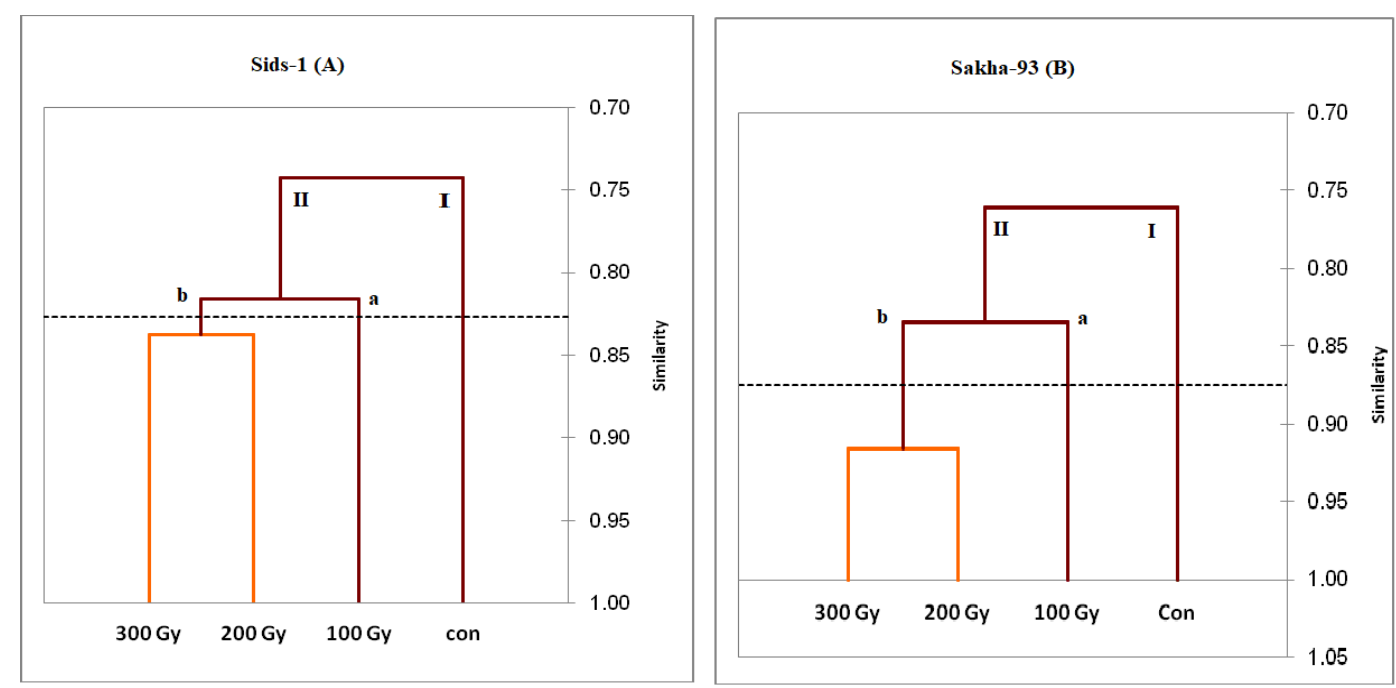

Fig. 5 Dendrograms for the irradiated and un-irradiated two Egyptian wheat cultivars Sids-1 (A); (Con, 100, 200, and 300 Gy) and Sakha-93 (B); (Con, 100, 200, and 300 Gy) based on similarity coefficients of ISSR data. Con = control. under water-stress and identified five markers for each physiological linked to leaf chlorophyll content, flag leaf senescence and cell membrane stability traits, respectively, as indicator for drought tolerance gene in wheat. These markers might be used for marker-assisted selection. Iqbal et $\mathrm{al}^{39}$ showed that the wheat genotype association with the levels of proline during induced drought stress and the relationship between pattern of drought responsive biochemical attributes and DNA markers in the selected wheat genotypes was recognized to select drought tolerant genotypes. In the same concern, Aly et $\mathrm{al}^{40}$ demonstrated that peroxidase and polyphenol oxidase activity and gene expressions can be used as biochemical and molecular markers to detect the resistance or susceptibility nature of wheat cultivars against salinity in integration with gamma irradiation.

\section{Cluster analysis as revealed by ISSR}

The genetic variations among the control (unirradiated) and irradiated two wheat cultivars Sids1 and Sakha-93 were determined by Jaccard's genetic similarity coefficients, ranged from 0.614 and 0.916 with an overall mean of 0.825 and 0.875 for Sids-1 and Sakha-93, respectively, depending on ISSR marker. The UPGMA cluster analysis of Jaccard's similarity coefficients produced a dendrogram (Fig. 5) which showed the genetic relationship among the un-irradiated and irradiated samples for both cultivars. The analysis illustrated that $\gamma$ irradiated for the two cultivars and the control fell 
into two main clusters. The first main cluster $I$ composed of the control, while the second cluster II involved two groups: the first group (a): comprised of $100 \mathrm{~Gy}$. The second group (b) involved the doses 200 and 300 Gy. Irradiation treatments applied in this study were succeeded in inducing genetic variations among molecular and phenotypic levels of the two wheat cultivars. It was found that the most genetic distance was more pronounced in Sids- 1 than in Sakha-93. These cluster analyses, showed true variation among control and irradiation treatments for both cultivars. This variation can be useful in wheat breeding programs by selection. This agreed with, Singh and Datta ${ }^{28}$, who demonstrated that gamma irradiation, encouraged phenotypic changes in wheat. The molecular analysis of groundnut using ISSR markers has shown that gamma ray irradiation at a dose of $100 \mathrm{~Gy}$ increased the level of genetic variability ${ }^{41}$. The difference between the highest and the lowest values of genetic distance showed a wide range of variability among the accessions evaluated ${ }^{42}$.

It could be summarized that using these advanced molecular techniques, new genes can be potentially identified by the plant breeders as the result of in vitro mutagenesis treatments. The results showed changes in non-irradiated and irradiated treatments, based on inter microsatellite length polymorphism. Hence it can be concluded that gamma ray treatment was an effective way for mutation be induction in wheat and the mutants could successfully identified through ISSR analysis. Hence the recent progress in mutation breeding studies in relation with new technologies is quite important to contribute new advancement to plant breeding programs.

Acknowledgements: Authors would like to thank the Atomic Energy Authority for their support and Ministry of Scientific Research for funding this study through the frame of Tunisia-Egypt cooperation project, fourth call, cod No. 14/4/30.

\section{REFERENCES}

1. Campuzano GE, Slafer GA, Miralles J (2012) Differences in yield, biomass and their components between triticale and wheat grown under contrasting water and nitrogen environments. Field Crops Res 128, 167-179.

2. Karakas O, Gurel F, Uncuoglu AA (2010) Exploiting a wheat EST database to assess genetic diversity. Genet Mol Biol 33, 719-730.

3. Hayden MJ, Tabone TL, Nguyen TM, Coventry S, Keiper FJ, Fox RL, Chalmers KJ, Mather DE, et al (2010) An informative set of SNP markers for molecular characterization of Australian Barley Germplasm. Crop Past Sci 61, 70-83.

4. Gostimsky SA, Kokaeva ZG, Konovalov FA (2005) Studying plant genome variation using molecular markers. Russ J Gen 41, 378-388.

5. Gaafar RM, Hamouda M, Badr A (2016) Seed coat color, weight and eye pattern inheritance in gammarays induced cowpea M2-mutant line. J Genet Eng Biotechnol 14, 61-68.

6. Ben El Maati F, Jlibene M, Moumni M (2004) Study of the polymorphism of common wheat using ISSR markers. J Food Agri Environ 2, 121-125.

7. Barakat MN, Al-Doss AA, Moustafa KA, Ibrahim E, Elshafei AA (2010) Morphological and molecular characterization of Saudi wheat genotypes under drought stress. J Food Agri Environ 8, 220-228.

8. Heidarieh M, Mirvaghefi A, Akbari M, Farahmand H, Sheikhzadeh N, Shahbazfar A, Behgar M (2012) Effect of dietary Ergosan on growth performance, digestive enzymes, intestinal histology, hematological parameters and body composition of rainbow trout (Oncorhynchus mykiss). Fish Physiol Biochem 38, 1169-1174.

9. Borzouei A, Kafi M, Sayahi R, Rabiei E, Sayad Amin P (2013) Biochemical response of two wheat cultivars (Triticum aestivum L.) to gamma radiation. Pak $J$ Bot 45, 473-77.

10. Ashraf M, Cheema AA, Rashid M, Qamar Z (2003) Effect of gamma rays on M1 generation in Basmati rice. Pak $J$ Bot 35, 791-795.

11. Sakin MA, Gökmen S, Yildirim A, Belen S, Kandemir $\mathrm{N}$ (2005) Effects of cultivar type on yield and quality of popcorn (Zea mays everta). New Zeal J Crop Hortic Sci 33, 17-23.

12. Kiong A, Ling Pick A, Grace Lai SH, Harun, AR (2008) Physiological responses of Orthosiphon stamineus plantlets to gamma irradiation. Am-Eurasian J Sustain Agric 2, 135-149.

13. Kovács E, Keresztes A (2002) Effect of gamma and UV-B/C radiation on plant cell. Micron 33, 199-210.

14. Aly AA, Maraei RW, Ayadi S (2018) Some biochemical changes in two Egyptian bread wheat cultivars in response to gamma irradiation and salt stress. Bulg $J$ Agric Sci 24, 50-59.

15. Mengoni A, Gori A, Bazzicalupo M (2000) Use of RAPD and microsatellite (SSR) variation to assess genetic relationships among populations of tetraploid alfalfa, Medicago sativa. Plant Breed 119, 311-317.

16. Vernon LP, Seely GR (1966) The Chlorophylls: Physical, Chemical and Biological Properties, 1st edn, Academic Press, New York.

17. Bates LS (1973) Rapid determination of free proline for water-stress studies. Plant Soil 39, 205-207.

18. Duncan DB (1955) Multiple range and multiple 'F' tests. Biometrics 11, 1-42. 
19. Prevos A, Wilkinson MJ (1999) A new system for comparing PCR primers applied to ISSR fingerprinting of potato cultivars. Theor Appl Genet 98, 107-112.

20. Borzouei A, Kafi M, Khazaei H, Naseriyan B, Majdabad A (2010) Effects of $\gamma$ radiation on germination and physiological aspects of wheat (Triticum aestivum L.) seedlings. Pak J Bot 42, 2281-2290.

21. Strid A, Chow W, Anderson JM (1990) Effects of supplementary ultraviolet-b radiation on photosynthesis in Pisum sativum. Biochim Biophys Acta 1020, 260-268.

22. Alikamanoglu S, Yaycili O, Sen A (2011) Effect of gamma radiation on growth factors, biochemical parameters, and accumulation of trace elements in soybean plants (Glycine max L. Merrill). Biol Trace Elem Res 141, 283-293.

23. Akshatha K, Chandrashekar R, Somashekarappa H, Souframanien J (2013) Effect of gamma irradiation on germination, growth, and biochemical parameters of Terminalia arjuna Roxb. Radiat Prot Environ 36, 38-44.

24. Beyaz R, Sancak C, Çiğdemyildiz C, Şebnemkuşvuran S, Yildiz M (2016) Physiological responses of the M1 sainfoin (Onobrychis viciifolia Scop) plants to gamma radiation. Appl Radiat Isot 118, 73-79.

25. Irigoyen JJ, Emerich DW, Sanchez-Diaz M (1992) Water stress induced changes in concentrations of proline and total soluble sugars in nodulated alfalfa (Medicago sativa) plants. Physiol Plant 84, 55-60.

26. Tyree MT, Jarvis PG (1982) Water in tissue and cells. In: Lange OL, Nobel PS, Osmond OB, Ziegler H (Eds) Encyclopedia of Plant Physiology, Springer, Berlin, pp 36-77.

27. El-Aziz MHA, Zaied KA, El-Gendy SEA, Abd ElGawad NA (2017) Evaluation of irradiated okra based on agronomical traits and RAPD markers. Assiut J Agric Sci 48, 81-96.

28. Singh B, Datta PS (2009) Gamma irradiation to improve plant vigour, grain development, and yield at-tributes of wheat. Rad Phys Chem 79, 139-143.

29. Badr A, El-Shazly HH, Halawa MM (2014) Cytological effects of gamma radiation and its impact on growth and yield of M1 and M2 plants of cowpea cultivars. Cytologia 79, 195-206.

30. Žiarovská J, Ražná K, Labajová M (2013) Using of inter microsatellite polymorphism to evaluate gamma irradiated Amaranth mutants. Emir J Food Agric 25, 673-681.

31. Chen Y, Peng Z, Wu C, Ma Z, Ding G, Cao G, Ruan $S$, Lin S (2017) Genetic diversity and variation of Chinese fir from Fujian province and Taiwan, China, based on ISSR markers. Plos One 12, ID e0175571.

32. Komarova LV, Kostitsyna NV, Boronnikova SV, Melnikova AG (2018) Genetic structure of natural populations of starlet (Acipenser ruthenus L.) in the catchment basins of the Kama and Ob rivers based on polymorphic ISSR markers. Agrobiology 53, 337-347.

33. Manova V, Gruszka D (2015) DNA damage and repair in plants- from models to crops. Front Plant Sci 6, ID 885.

34. Hanafy RS, Akladious SA (2018) Physiological and molecular studies on the effect of gamma radiation in fenugreek (Trigonella foenum-graecum L.) plants. $J$ Genet Eng Biotechnol 16, 683-692.

35. Mejri S, Mabrouk Y, Voisin M, Delavault P, Simier P, Saidi M, Belhadj O (2012) Variation in quantitative characters of faba bean after seed irradiation and associated molecular changes. Afr J Biotech 11, 8383-8390.

36. Heiba SAA, Haiba AAA, Abdel-Rahman HM (2019) Determination of genetic markers in some Egyptian varieties of wheat and barley under salt and drought stresses. Asian J Crop Sci 11, 59-70.

37. Xu Y, Wang JY, Bonos, SA, Meyer WA, Huang BR (2018) Candidate genes and molecular markers correlated to physiological traits for heat tolerance in fine fescue cultivars. Int J Mol Sci 19, 116-136.

38. Elshafei AA, Saleh M, Al-Doss AA, Moustafa KA, AlQurainy FH, Barakat MN (2013) Identification of new SRAP markers linked to leaf chlorophyll content, flag leaf senescence and cell membrane stability traits in wheat under water-stressed condition. Aus $J$ Crop Sci 7, 887-893

39. Iqbal MJ, Maqsood Y, Abdin ZU, Manzoor A, Hassan M, Jamil A (2016) SSR markers associated with proline in drought tolerant wheat germplasm. Appl Biochem Biotechnol 178, 1042-1052.

40. Aly AA, Maraei RW, Aldrussi I (2019) Changes in peroxidase and polyphenol oxidase activity and transcript levels of related genes in two Egyptian bread wheat cultivars (Triticum aestivum L.) affected by gamma irradiation and salinity stress. Bangl J Bot 48, 177-186.

41. Tshilenge-Lukanda L, Nkongolo KKC, Narendrula R, Kalonji-Mbuyi A, Kizungu RV (2012) Molecular characterization of groundnut (Arachis hypogaea L.) accessions from a gene pool: application of gamma ray radiations. J Plant Breeding Crop Sci 4, 175-183.

42. Oladosu Y, Rafii MY, Abdullah N, Hussin G, Ramli A, Rahim HA, Miah G, Usman MG (2016) Principle and application of plant mutagenesis in crop improvement: a review. Biotechnol Biotechnol Equip 30, 1-16. 